\title{
放射流式透水試験器の試作実験について
}

\author{
正員 酒 井 左 武 郎* \\ 正員川北米良**
}

\section{ON THE TRIAL PRODUCTION OF RADIAL FLOW PERMEAMETER AND ITS TEST}

By Saburo Sakai, C.E. Member and Yoneo Kawakita, C.E. Member.

Synopsis : The radial flow permeameter is used to define the coefficient of permeability of soil, bymeans of two dimensional seepage flow occuring horizontally throughout the soil sample, caused by making a suitable water pressure act on the porous pipe that is set in the middle of the cylindrical sample (See Fig. 1 and Phots 1 and 2).

From the testing results of this newly-built apparatus, the writers are convinced to have been able to correct some of the common faults and errors of the conventional testers that have hitherto been in use.

要旨 放射流式透水試験器は, 円柱試料土の中心立てられた多孔管に適度の水圧を作用させ, 試料 を通して水平な 2 次元的放射浸透流を生ぜしめることにより，透水係数を求める試験器である（図一1 招よび 写真一1，2 参照)。

筆者等はこの試験器の試作実験により, 従来の透水試験器が共通に持つ欠陷の幾つかを是正し, かつ 信頼性のある測定結果を得ることができだ**。

1. 緒言

圧密試験の結果から透水係数を求める場合を除けば, 従来使用されて来た室内実験用の透水試験器は, 一般に 陚験器の内側の壁面と試料土との境界面からの漏水量がかなり多く，これを防止することがはなはだ困難であ り，試料の上面が試験中飞攪乱されたり，あるいは試験時間が長びくと試料の自由表面が膨張したりする恐れが

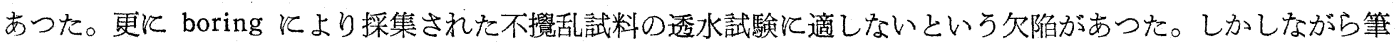
者は放射流式透水試験器の考案により, これ等の欠陥を除去し, 室内実験飞よる土の透水係数の測定に一層信頼 性を増すことができた。また從来透水係数が $10^{-6} \mathrm{~cm} / \mathrm{sec}$ 程度以下の土の場合には, 透水係数の測定に長時間を 要したのであるが，この不便を解消するため放射流式透水試験器の使用に際し，Boyle の法則を導入した新しい 変水頭測定法 (本文, 変水頭測定法一II) を案出し，これが高い精度を得ることができることを確認した。

な物 放射流式透水試験器 なる名は筆者の命名せるものである。

\section{2. 試 験 装}

放射流式透水試験器は 図一1 および 写真一1,2 と示すような装 置で，その構造の主要部分は(1)多孔円筒，(2)多孔管，(3)蓋板，(4)底 板よりなる。多孔円筒の内径は boring により採集される core の直径化合わせて作り，不攪乱試料の透水試験を行う場合の便をは かることとする。

試験汇際しては蓋板(3)と底ネジ(5)をはずし， core tubeをツバ6 そ連結し，tube 内の不攪乱試料を静かに多孔円筒(1)の内部に移す。 次に試料土の上面を所定の寸法に削りならした後，上下面(7)(8)の空 間部分飞溶融した paraffinを注入乙凝固し始めないうちと蓋板(3)を 取り付けネジ(9を締める。多孔管(2)の中に入つた土は棒で押し出 し中を brush でよく掃除してからネシ (5)をはめる。最後飞連結金

\section{図-1 放射流式透水試験器の構造}

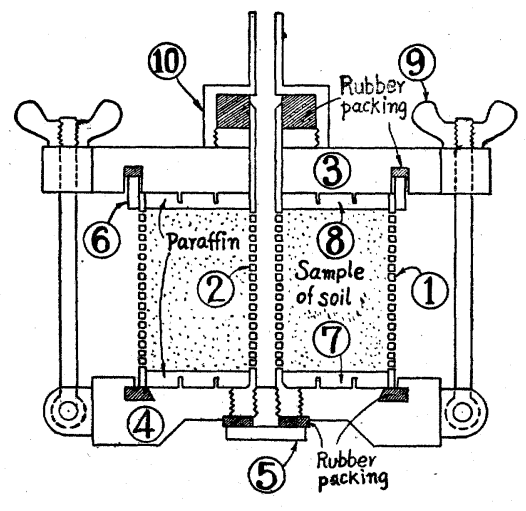

* 日本大学講師, 理工学部土木工学教室 ** 日本大学助手, 理工学部土木工学教室

*** 1958 年 5 月 24 日, 第 13 回年土木学会次学術講演会にて発表 
写真-1 放射流式透水試験器の試作品

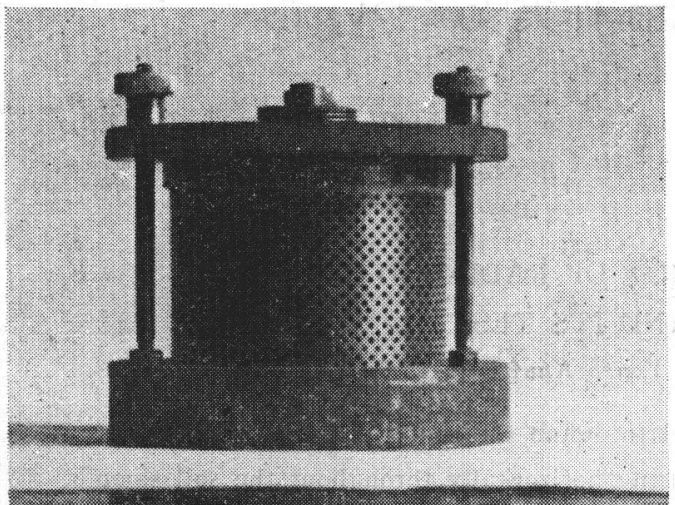

写真一2 試作の放射流式透水試験器の各部品

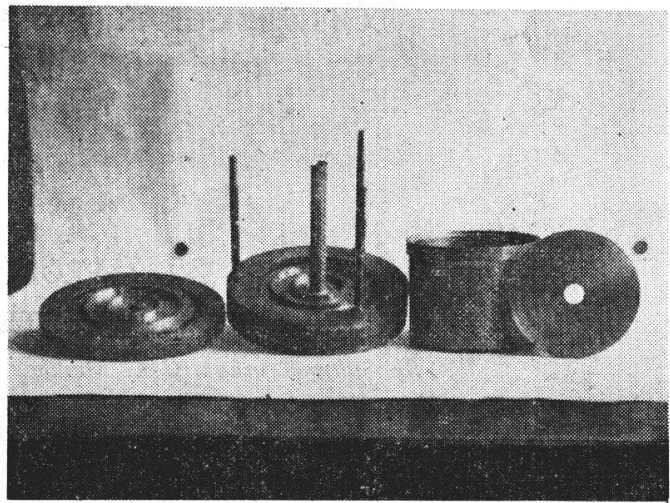

具10亿より透水試験器と水頭負荷装置とを連結し, 溢流口のある容器の中に, 多孔管が鉛直になるよう飞試験器 を据兄置き, 容器の中に水を満たす。このようにして試験準備が完了すれば, 水頭負荷装置に Darcy の法則が 成立する範囲の適度の水頭を試料応じて作用させ, 試験器の中央すなわち試料の中心軸に直立する多孔管の側 壁を透して多孔円筒の外周に向かる水平方向の 2 次元的放射状浸透流を生ぜしめ, 次に述べる定水頭測定法ある いは変水頭測定法一I,II のいずれかの測定法により透水係数を求める。

\section{3. 定水頭測定法}

定水頭測定法は一般と試料が砂質系で, 透水係数が $10^{-4} \mathrm{~cm} / \mathrm{sec}$ 程度以上の場合に適用される。図一2 亿示す よろに，試験器の中央の多孔管飞作用する水頭 $H$ 飞一定飞確保し，ある時 間内に試料中を浸透して流出した水の流量 $Q_{0}$ をメスシリンダーで測定する ことにより，その試料の透水係数を求める。この場合に試料中に生ずるの放 射状浸透流は定常運動をなす。ゆ学を動水勾配招よび透水係数は次の上うに して求められる。

(a) 動水勾配 極座標 $(r, \theta)$ を図一2 のように定めれば，湜透流付対 する連続の条件と Darcy の法則から, 試料中の任意の点 $(r, \theta)$ の水頭 $h$ は Laplace の方程式

$$
\frac{\partial}{\partial r}\left(r \frac{\partial h}{\partial r}\right)+\frac{1}{r} \frac{\partial^{2} h}{\partial \theta^{2}}=0
$$

で表わされる11。この試験器に颣いては，浸透流は多孔管を中心とする一様 な放射流と考光られるから $\partial h / \partial \theta=0$ ，また $H=$ const. であるから $h$ は $r$ のみの関数となる。従つて (1) は

$$
\frac{d}{d r}\left(r \frac{d h}{d r}\right)=0 \text {. }
$$

図-2 定水頭测定法

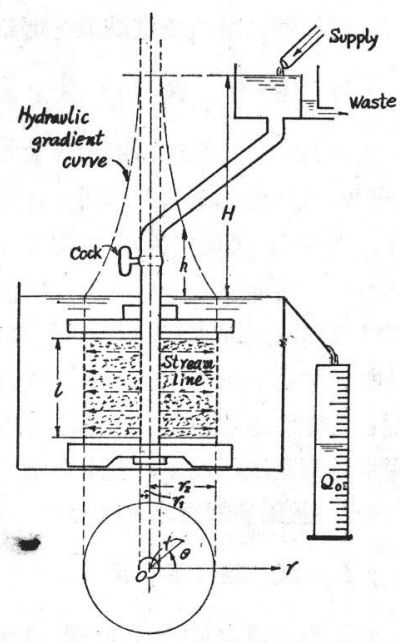

図一2 と杼いて明らかなどとく，境界条件は

$$
\left.\begin{array}{l}
(h)_{r=r_{1}}=H, \\
(h)_{r=r_{2}}=0 .
\end{array}\right\}
$$

ここに，2 $r_{1}$ は多孔管の外径， $2 r_{2}$ は多孔円筒の内径を示す。（3）を満足するように（2）を解けば，動水勾 配線の方程式

$$
h=\frac{H \log \left(\boldsymbol{r}_{2} / \boldsymbol{r}\right)}{\log \left(\boldsymbol{r}_{2} / \boldsymbol{r}_{1}\right)}
$$

が得られる。(4)を $r$ について微分すれば試料中各点の動水勾配 $i$ が次式で与光られる。

$$
i=-\frac{d h}{d r}=\frac{H}{r \log \left(r_{2} / r_{1}\right)}
$$

(b) 透水係数 長さ $l$ の円柱試料土の中心線より半径 $r$ の距離にある一透水断面 $2 \pi r l$ を透して, 時刻 $t_{1}$ から $t_{2}$ までの間に流れる流量 $Q_{0}$ は Darcy の法則 $v=-k d h / d r$ に (5) を代入して

$$
Q_{0}=2 \pi r l v\left(t_{2}-t_{1}\right)=\frac{2 \pi l k H\left(t_{2}-t_{1}\right)}{\log \left(r_{2} / r_{1}\right)},
$$


ここル, $v$ は武料中の半径 $r$ の点の浸透流速, $t_{1}$ は測定開始時刻, $t_{2}$ は測定終了時刻, $k$ は武料の透水係数 とする。

ゆ光に，選定した一定水頭 $H$ とついて時刻 $t_{1}, t_{2}$ とその間の流量 $Q_{0}$ を測定すれば，(6) より透水係数は

ただし

$$
\begin{aligned}
& k=\frac{e Q_{0}}{l H\left(t_{2}-t_{1}\right)}, \\
& \lambda=\frac{\log \left(r_{2} / r_{1}\right)}{2 \pi}=0.36647 \log _{10}\left(\frac{r_{2}}{r_{1}}\right)
\end{aligned}
$$

そより求められる。ス恃無次元定数で, 試験器の寸法のみにより定まる試験器定数である。

\section{4. 変水頭測定法一I}

変水頭測定法一 I は透水係数が $10^{-4} \sim 10^{-7} \mathrm{~cm} / \mathrm{sec}$ 程度となるような silt あるいは粘土質の土の場合に適用さ

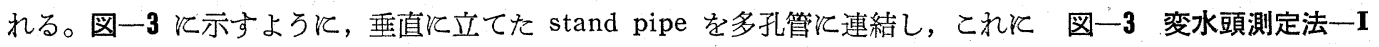
水を入れて円柱試料の中央に適度の水頭を作用させ，時間の経過とともに降下する stand pipe 内の水頭を觀測し，次の計算により透水係数抢よび動水勾配を求める。

（a）透水係数 ある時刻湉ける stand pipe 内の水頭を $H$, stand pipe の 内部断面積を $a$, 長さ $l$ の円柱試料の中心線より半径 $r$ の点の時刻 $t$ の浸透流速 呿よび水頭をそれぞれ $v$ 呿よび $h$ とすれば， stand pipe 内を単位時間々降下す る水量と試料中の一透水断面 $2 \pi r l$ を単位時間に透過する流量とが等しくなけれ ばならないから，次の等式が成立する。

$$
2 \pi r l v=-a \frac{d H}{d t}
$$

浸透流速 $v$ K Darcy の法則 $v=-k \partial h / \partial r$ を適用すれば

$$
\frac{\partial h}{\partial r}=\frac{a}{2 \pi l k} \frac{d H}{d t} \frac{1}{r} \text {. }
$$

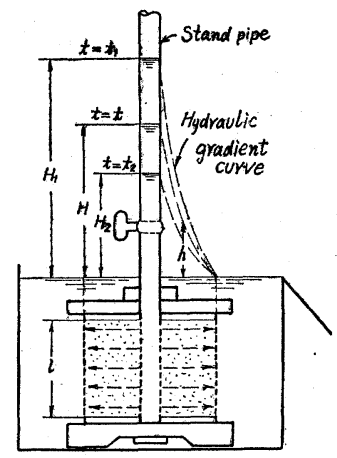

(10) 飞括いて $h$ は $r$ 招よび $t$ の関数, $H$ は $t$ のみの関数である。この場合の初期条件並びそ境界条件は

$$
\begin{aligned}
& (h)_{r=r_{2}}=0 \text {, } \\
& (H)_{t=t_{1}}=H_{1} \text {, ) } \\
& \text { (H) } t_{t=t_{2}}=H_{2} \text {. }
\end{aligned}
$$$$
(h)_{r=r_{1}}=H(t) \text {, }
$$

ただし， $H_{1}$ は測定開始時刻 $t_{1}$ 飞抬ける stand pipe 内の水頭， $H_{2}$ は測定終了時刻 $t_{2}$ の水頭である。(10)を r そついて積分し，(11）を満足させれば

$$
h=\frac{a \log \left(r / r_{2}\right)}{2 \pi l k} \frac{d H}{d t}
$$

さらに(14) に (12) の条件を用いれば

$$
-\frac{2 \pi l k}{a \log \left(r_{2} / r_{1}\right)} d t=\frac{d H}{H}
$$

（15）を積分すれば

$$
\mathrm{CH}=e^{-\frac{2 \pi l k t}{a \log \left(r_{2} / r_{1}\right)}}
$$

ただし，C は積分常数である。(16) 飞境界条件 (13) を与兄て $C$ を消去すれば

$$
k=\frac{\lambda a}{l\left(t_{2}-t_{1}\right)} \log \left(\frac{H_{1}}{H_{2}}\right)
$$

ここに, ネは (8) で与えられる無次元の試験器定数である。従つて, 測定初期に $t_{1}, H_{1}$ を観測し測定終了時刻 飞 $t_{2}, H_{2}$ を観測すれば，(17) より透水係数が求められる。

（b）動水勾配（16）飞（13）の最初の条件式を用いて積分常数 $C$ を定めれば

$$
C=\frac{1}{H_{1}} e^{-\frac{2 \pi l k t_{1}}{a \log \left(r_{2} / r_{1}\right)}},
$$

これを(16) と代入すれば stand pipe 内の水頭降下の状驡が次式によつて表わされる。

$$
H=H_{1} e^{-\frac{l k\left(t-t_{1}\right)}{a \lambda}}
$$




$$
u=-\frac{d H}{d t}=\frac{l k H_{1}}{a \lambda} e^{-\frac{l k\left(t-l_{1}\right)}{a \lambda}} .
$$

ゆ无飞動水勾配線は（14）飞（19）を代入して

$$
h=\frac{H_{1} \log \left(\boldsymbol{r}_{2} / \boldsymbol{r}\right)}{2 \pi \lambda} e^{-\frac{l k\left(t-t_{1}\right)}{a \lambda}} .
$$

従つて試料中各点の任意時刻に扮ける動水勾配 $i$ は (20)を $r$ とついて偏微分することにより

$$
i=-\frac{\partial h}{\partial r}=\frac{1}{2 \pi \lambda r} H_{1} e^{-\frac{l k\left(t-t_{1}\right)}{a \lambda}}
$$

で与觉られ。

\section{5. 変水頭測定法一II}

透水係数が $10^{-6} \mathrm{~cm} / \mathrm{sec}$ 以下の斌料になると, 前述の測定法で は高水頭を作用させると不便な場合があり，また測定飞長晊間を 要する。このような試料の場合飞変水頭測定法一IIを用いれば比 較的短時間飞信頼性のある透水係数を測定することができ便利で ある。変水頭測定法一IIは 図一4 亿示すごとく 70 80\% をで水 を満たした pressure tank と試験器とを, 高圧に対して断面の 変形しない pipe で連結し， tank と圧控空気を送りその压力 manometer で測定する。Pressure tank 内の纴力が適当の值に なつたとき $\operatorname{cock} \mathrm{A}$ を閉じる。この時 $\operatorname{cock} \mathrm{B}$ は閉ざされてい るものとする。次に cock B を開き測定を開始する。測定開始時 刻の pressure tank 内の圧力とある時間経過した後のその tank 内の圧力とを manometer で測定すると同時に，その時間中の浸

図-4 变水頭測定法-II

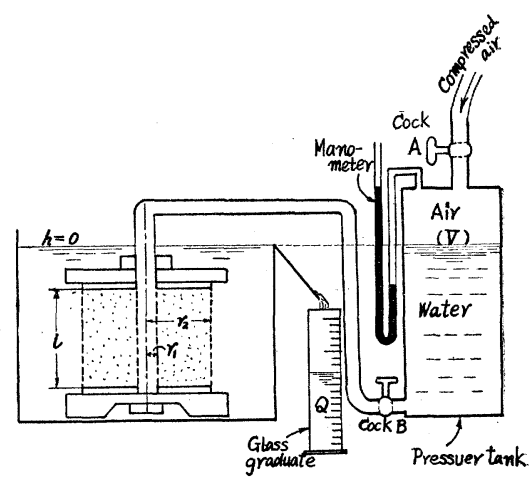
透流量をメスシリンダーで測定することとより透水係数が求められる。ただし測定中の温度は一定に確保される ものとする。次にこの測定法に括ける透水係数拉よび動水公配の計算式を誘導する。

(a) 透水係数 測定開始特刻を $t_{1}$, その時刻の pressure tank 内の圧力招よび空気容積をそれぞれ $p_{1}$ 特 よび $V$, 測定終了時刻を $t_{2}$, その時刻の pressure tank 内の圧力を $p_{2}, t_{1}$ から $t_{2}$ までの時間中の流量を $Q_{0}$, $t_{1}$ から任意時刻 $t$ までの時間中の流量を $Q$ とすれば， ある時刻 $t$ 飞和ける算位時間流量 $d Q / d t$ と長さ $l$ D 円柱試料の中心線より半径 $r$ の距離にある一透水断面を浸遥する単位時間流量 $2 \pi r l v$ との間次次の等式が成立 する。

$$
\frac{d Q}{d t}=2 \pi r l v
$$

浸透流速 $v$ K Darcy の法則を適用すれぼ

$$
\frac{d Q}{d t}=-2 \pi r l k \frac{\partial h}{\partial r} .
$$

他方, 測定中任意の時刻 $t$ 飞括ける pressure tank 内の圧力を $p$ で表わせば，Boyle の法則により

$$
p_{1} V=p(V+Q), \quad \therefore Q=V\left(\frac{p_{1}}{p}-1\right) \cdots
$$

なる関係式を得る。ただし測定中の温度は一定に確保されるるのとする。(24)を

$$
\frac{d Q}{d t}=-\frac{V p_{1}}{p^{2}} \frac{d p}{d t}
$$

(23) と（25）より $d Q / d t$ を消去すれば

$$
\frac{\partial h}{\partial r}=\frac{V p_{1}}{2 \pi l k} \frac{1}{p^{2}} \frac{d p}{d t} \frac{1}{r}
$$

初期条件括よび境界条件は

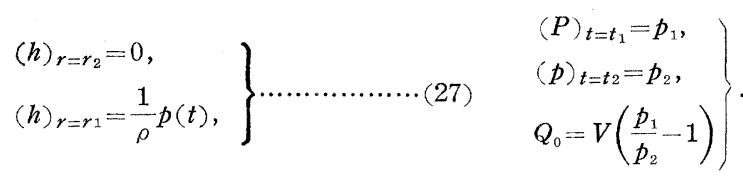

ただし， 


$$
h=\frac{V p_{1} \log \left(r / r_{2}\right)}{2 \pi l k} \frac{1}{p^{2}} \frac{d p}{d t},
$$

$$
d t=-\frac{\rho V p_{1} \log \left(r_{2} / r_{1}\right)}{2 \pi l k} \frac{1}{p^{3}} d p .
$$

さらと条件 (28) を用い，(30) の左辺を $t_{1}$ から $t_{2}$ まで，右辺を $p_{1}$ から $p_{2}$ まで積分すれぼ

ゆえ江

$$
\begin{aligned}
t_{2}-t_{1} & =\frac{\lambda}{2} \frac{\rho Q_{0} p_{1} p_{2}}{l k\left(p_{1}-p_{2}\right)}\left(\frac{1}{p_{2}{ }^{2}}-\frac{1}{p_{1}{ }^{2}}\right), \\
k & =\frac{\lambda \rho Q_{0}\left(p_{1}+p_{2}\right)}{2 l\left(t_{2}-t_{1}\right) p_{1} p_{2}} \ldots \cdots \cdots \cdots \cdots \cdots
\end{aligned}
$$

ここに, $\lambda$ は (8) で与兄られる試験器定数である。従つて, 時刻 $t_{1}, t_{2}$ の pressure tank 内の圧力 $p_{1}, p_{2}$ と 乞の時間中の浸透流量 $Q_{0}$ を測定すれば，透水係数は（31）飞より求められる。

(b) 動水勾配 (30) を積分し，

(28) の初期条件 $(p)_{t=t_{1}}=p_{1}$ を満足するようと積分常数を定め, 第 3 式を用いて $V$ を消去すれば

$$
t=\frac{\lambda \rho V p_{1}}{2 l k p^{2}}+t_{1}-\frac{\lambda \rho V}{2 l k p_{1}}, \quad \quad p=\sqrt{\frac{\lambda \rho Q_{0} p_{1} p_{2}}{2 l k\left(p_{1}-p_{2}\right)\left(t-t_{1}\right)+\lambda_{\rho} Q_{0}\left(\frac{p_{2}}{p_{1}}\right)}} .
$$

(32) は pressure tank 内の圧力の時間的飞減少する状態を表わす式である。ゆえに試料中央の多孔管の側壁 飞作用する水頭 $H$ の時間的変化は $p / \rho$ とよつて示される。また動水勾配線は (29) と (30)を用いて $d p / d t$ を 消去したのち, $p$ 飞(32) を代入すれば

$$
h=\frac{\log \left(\frac{r_{2}}{r}\right)}{2 \pi \lambda} \sqrt{\frac{\lambda Q_{0} p_{1} p_{2}}{2 \rho l k\left(p_{1}-p_{2}\right)\left(t-t_{1}\right)+\lambda \rho^{2} Q_{0}\left(\frac{p_{2}}{p_{1}}\right)}} .
$$

動水勾配 $i$ は (33) を $r$ そついて偏微分することにより次式で与えられる。

$$
i=-\frac{\partial h}{\partial r}=\frac{1}{2 \pi \lambda r} \sqrt{\frac{\lambda Q_{0} p_{1} p_{2}}{2 \rho l k\left(p_{1}-p_{2}\right)\left(t-t_{1}\right)+\lambda \rho^{2} Q_{0}\left(\frac{p_{2}}{p_{1}}\right)}} .
$$

\section{6. 動水勾配および浸透流速の最大最小值の関係}

以上飞述べた放射流式透水試験器による透水係数の三つの測定法（定水頭測定法，変水頭測定法一I, II）飞招 いては，動水勾配はそれぞれ（5)，(21)，(34）の各式で求められるが，これ等はすべて共通と

$$
i=\frac{1}{2 \pi \lambda} \frac{H}{r}
$$

なる形式で表わされる。すなわち, 動水勾配 $i$ は中央水頭 $H$ 飞比例し, 半径 $r$ 飞逆比例する。ゆ充湤射流 式透水試験器に和いては, 動水勾配の最大 $\left(i_{\max }\right)$ 特よび最小 $\left(i_{\min }\right)$ となる点はとれぞれ試料中央部 $r=r_{1}$ 物 よび試料の外周 $r=r_{2}$ の点であつて, それ等の值は (35) より

$$
\left.\begin{array}{l}
i_{\max }=\frac{1}{2 \pi \lambda} \frac{H}{r_{1}} \\
i_{\min }=\frac{1}{2 \pi \lambda} \frac{H}{r_{2}} .
\end{array}\right\}
$$

また浸透流速 $v$ は Darcy の法則とより $v=k i$ であるから，(36)を用いて次の関係式を得る。

$$
\frac{i_{\max }}{i_{\min }}=\frac{v_{\max }}{v_{\min }}=\frac{r_{2}}{r_{1}}
$$

すなわち, 放射流式透水試験器に挌ける動水勾配拉よび浸透流速の最大值と最小值の比は多孔円筒の内径と多 孔管の外径の比㳊等しい。

\section{7. 実 験 結 果}

試作実験て招いて使用した放射流式透水試験器は， boring そより採集される core の直径 3 in. の不攪乱試: 料を対象とし, 多孔管の外径 $2 r_{1}=1.0 \mathrm{~cm}$, 多孔円筒の内径 $2 r_{2}=7.4 \mathrm{~cm}$, 試料の長さ $l=5 \mathrm{~cm}$ とした。もちろ ん攪乱試料の試験にもこの試験器を用いた。写真一1 はこの試作詿験器の全貌を示し, 写真一2 はとの構造を分 解して各部品を示したものである。

(a) 試作試験器に対する透水係数の計算式怙よび動水勾配・浸透流速の最大最小值の関係 試作の試験器化 おいては試験器定数は (8) より $\lambda=0.3185$, 各測定值の単位を $H(\mathrm{~cm}), p_{1}, p_{2}\left(\mathrm{~g} / \mathrm{cm}^{2}\right), Q_{0}\left(\mathrm{~cm}^{3}\right),\left(t_{1}-t_{1}\right)(\mathrm{sec})$ 
己すれね゙透水係数 $k(\mathrm{~cm} / \mathrm{sec})$ は各測定法によりとれぞれ (7), (17), (31) より

定水頭測定法 : $\quad k=\frac{0.0637 Q_{0}}{H\left(t_{2}-t_{1}\right)} \cdots \cdots \cdots \cdots(38) \quad$ 変水頭測定法 $-\mathrm{I}: \quad k=\frac{0.2422}{t_{2}-t_{1}} \log _{10}\left(\frac{H_{1}}{H_{2}}\right) \cdots$

ただし，使用した stand pipe の内径 $1.45 \mathrm{~cm}, a=1.65 \mathrm{~cm}^{2}$ である。

変水頭測定法一II :

$$
k=\frac{0.0319 Q_{0}\left(p_{1}+p_{2}\right)}{\left(t_{2}-t_{1}\right) p_{1} p_{2}}
$$

ただし， $\rho 1 \mathrm{~g} / \mathrm{cm}^{3}$ とする。

動水勾配招よび浸透流速の最大最小值は各測定法に共通に（36), (37) より次のごとく計算される。

$$
\begin{gathered}
i_{\max }=\frac{1}{2 \times 3.14159 \times 0.3185} \times \frac{H}{0.5}=0.9994 \mathrm{H} \\
\therefore \quad i_{\max } H, \quad v_{\max }=k H, \quad \frac{i_{\max }}{i_{\min }}=\frac{v_{\max }}{v_{\min }}=7.4
\end{gathered}
$$

すなわち, 試作の放射流式透水武験器飞抛いては, 試料中央部 $\left(r=r_{1}\right)$ 飞生ずる最大動水勾配は, その時の $\mathrm{cm}$ 単位の中央水頭の読みの無次元数值にほぼ等しい。

(b) 新旧透水試験器の比較実験 次飞, 従来使用されて来た定水頭型特よび変水頭型透水試験器2) と, 新し く考案した放射流式透水試験器との比較実験を標準砂と関輯ローム々ついて, 種々間げき比を変えて行つた。こ 和等の試料の粒度分析の結果は 図一 9 亿示す。従来の透水試験器は, 試料土と側壁との接触面からの漏水を防 ぐために，そこに paraffin を医どこすことになつているが，その実行ははなはだめんどうで，かつ漏水の完全 な防止は不可能なため, この比較実験の場合は, 従来の透水試験器飞対して paraffin による漏水防止はしなか つた。次に新旧試験器を用いた場合の比較実験の結果を示っ。

i）標準砂の透水試験結果：放射流式透水試験器に対してほ前述の定水頭測定法を用い, 従来の定水頭型透水 試験器飞対しては, 試験器の内面と試料土との接触面からの漏水があるから，この漏水量を測定するためと透水 断面 $(A)$ を図一5のよう飞中心部 $\left(A_{1}\right)$ と側壁飞接触する周辺部 $\left(A_{2}\right)$ とに区分し，それぞれの部分からの流量 $Q_{1}$ 招よび $Q_{2}$ を測定し，漏水率招よび透水係数を次式で求內た。

$Q^{\prime}=$ 漏水量を含む全浸透流量, $Q=$ 補正浸透流量, $q=$ 漏水量, $H=$ 水頭, $l=$ 武料の高さ

$$
\left.\begin{array}{l}
Q=\frac{Q_{1}}{A_{1}} A, \quad Q^{\prime}=Q_{1}+Q_{2}, \quad q=Q^{\prime}-Q, \\
\text { 漏水率 }=\frac{q}{Q^{\prime}}, \quad k=\frac{Q l}{H . A}
\end{array}\right\}
$$

図一5 従来の定水頭 型透水試験器 の漏水量測定 装置

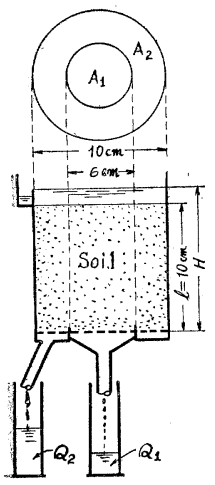

図一－＼cjkstart従来の定水頭型頭水試験器の漏 水率

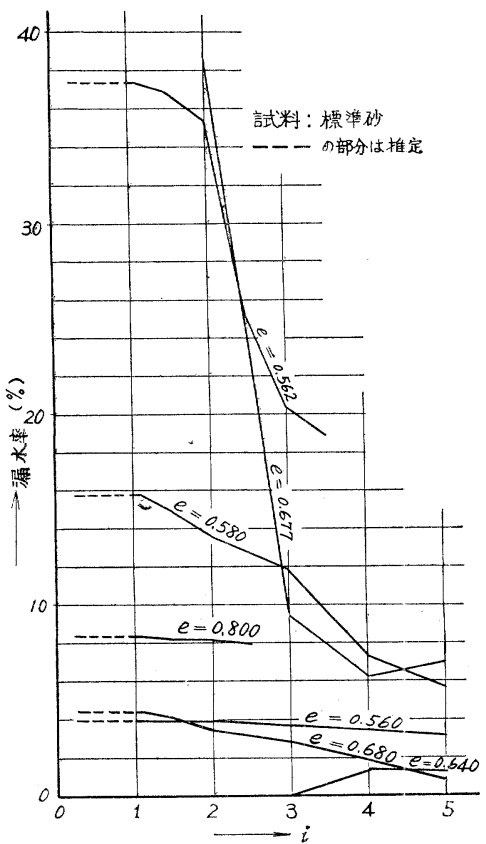

図一7＼cjkstart標準砂の透水試験結果

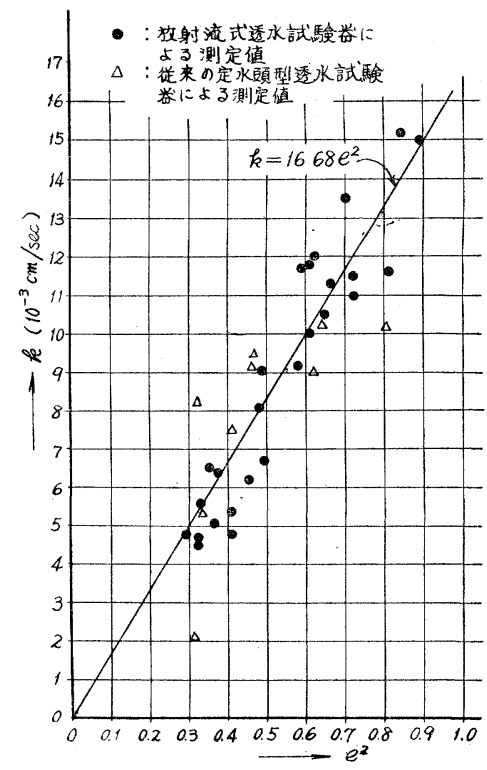


従来の定水頭型透水試験器を使用する場合は, 漏水率を (41) より求め動水勾配 $(i)$ と漏水率との関係を示せ ば 図一6のようである。すなわち, 漏水率は試験器への試料の詰めぐあいとより異なるが, 一試料についてい兄 ば，一般動水勾配が大きくなると従つて減少する傾向があり，その值は 4 40\% 程度である。ただし，この実 験飞招いては $Q_{1}, Q_{2}$ の測定のため, 試料の上面より水を流さねね゙ならなかつたので $i<1$ の部分を実験すること ができなかつた。しかしこの部分は Darcy の法則の成立範囲内 ${ }^{3), 4)}$ 飞あるから, 試料と試験器の内面との接触. 部の流れもD Darcy の法則飞従がうものとみなされるゆ光， $i<1$ の部分では漏水率はほぼ一定值をとるものと考 えることができる。

しかし放射流式透水試験器はこのような漏水は全くなく試料の攪乱や吸水膨張の恐れなく，作用させる水頭の 大きさを変えるにも自由で便利である。従つて, 從来の透水試験器より,一層信頼性のある試験をなすことがで きた。

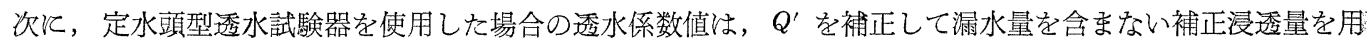
いて (41) で計算し, 放射流式透水試験器を用いた場合の透水係数值は (38) で求め, 両者の実験結果につい て, 透水係数 $(k)$ と試料の間げき比 $(e)$ の自乗との関係を示せ汭, 図一7のようである。この結果とよると $k$ と $e^{2}$ との間比例関係 $k=16.68 e^{2}$ があり D.W. Taylor の示した関係 ${ }^{5}$ が認められた。ただし, 測定值壮定水 頭型試験器を用いて補正流量から計算した值よりる, 放射流式质水試験器を用いた場合の方がはるかとばらつき が少ない。

ii) 関東ロームの透水試験結果 : 従来の 図一8 関東ロームの透水試験結果 変水頭型透水試験器を用いた場合と放射流 式透水試験器飞変水頭測定法一I 学適用乙 た場合との比較実験を関東ロームについて 行つた結果は図一8のごとくである。試験 器へ試料を詰め込む時の含水比は $40 \sim 50 \%$ 飽和度は 70 80\% である。変水頭型試験 器の試験結果は, いずれの場合も24 時間 飞試験器壁からの漏水率が 70 90\% る り，これを防止する paraffin jacket の実 施は技術的《むつかしく，この実験では成

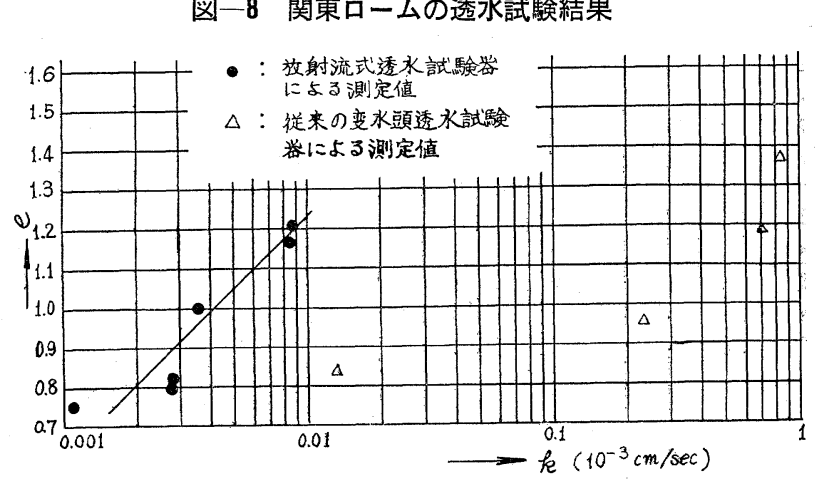
功しなかつたので，信頼性のある $k$ の值を測定することができなかつた。一般に，これまで $k=10^{-3} \sim 10^{-6} \mathrm{~cm} /$ sec の土は透水性が不安定で, 正確な測定值を得ることが困難でかなりの経験を要しだのであるが，関東ロー ムの $k$ はこの範囲飞属する。しかし放射流式透水試験器飞招いてね試験器の漏水は全くなく, 容易に信頼性の. 高い測定值を得ることができ，注ぼ D.W. Taylor の示した結果と同様な傾向が認められだ?。

(c) 圧密詰験器执よび放射流式透水試験器より求めた透水係数值の比較 この比較実験に用いた試料は, 地 下水面下より採集した silt ないし粘土質の不攪乱試料で, その結果は表一1のようである。すなわち圧密試験 器抢よび放射流式透水試験器の両者より求めた $k$ の值は相当近似し, 信頼度の高いことを示す。な物放射流式透 水試験器はこのような透水係数のきわめて小さい試料高い水頭を作用させてる漏水の恐れが全くないことを確 認した。

圧密試験器を用いた場合は, 最初の載荷段階の荷重強度 $0.2 \mathrm{~kg} / \mathrm{cm}^{2}$ 江対する透水係数を $\sqrt{t}$ 一法汇より次式 から求めた。

$$
k=\frac{a_{v} C_{v} r_{w}}{1+e}
$$

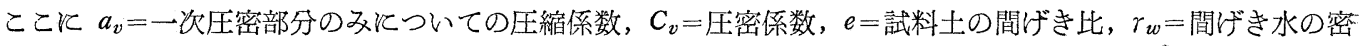
度。放射流式透水試験器を用いた場合は，変水頭測定法一I 物よび II を適用し，(39）あるいは（40）より透水 係数を求めた。

(d) 放射流式透水試験器による各種の土の透水実験例 最後汇武作武験器を用いて 図一9 亿示すような各 種の土について行つた透水試験例を，表一2 抢よび 図一10, 11 と示す。

\section{8. 結言}

以上の実験結果とより，新しく考案せる放射流式透水試験器は，従来使用されて来た定水頭型特よび变水頭型 
表一1 圧密試験器および放射流式透水試験器より求めた透水係数の比較

\begin{tabular}{|c|c|c|c|c|c|c|c|c|c|c|}
\hline \multirow{3}{*}{ 粒度による土の分類 } & \multicolumn{3}{|c|}{ 粒土配合（\%） } & \multirow{3}{*}{$\begin{array}{c}D_{60} \\
(\mathrm{~mm})\end{array}$} & \multirow{3}{*}{$\begin{array}{l}D_{10} \\
(\mathrm{mnm})\end{array}$} & \multirow{3}{*}{$\begin{array}{l}\text { 試験時 } \\
\text { 廊和 } \\
\text { 度 } \\
(\%)\end{array}$} & \multirow{3}{*}{$\mid \begin{array}{c}\text { 間げき比 } \\
e\end{array}$} & \multicolumn{3}{|c|}{ 透水係数 $k(\mathrm{~cm} / \mathrm{sec})$} \\
\hline & & \multirow[b]{2}{*}{ シルト } & \multirow[b]{2}{*}{ 粘 土 } & & & & & \multirow{2}{*}{$\begin{array}{l}\text { 放射流式透 } \\
\text { 水試験器* }\end{array}$} & \multicolumn{2}{|c|}{ 圧密試験器 } \\
\hline & 砂 & & & & & & & & $k^{* *}$ & $e^{* *}$ \\
\hline ンルト質ローム & 18 & 74 & 8 & 0.03 & 0.008 & 100 & 1.36 & $7.83 \times 10^{-7}$ & $4.87 \times 10^{-7}$ & 1.31 \\
\hline シルト質ローム & 25 & 68 & 7 & 0.05 & 0.01 & 100 & 1.32 & $2.90 \times 10^{-7}$ & $1.82 \times 10^{-7}$ & 1.28 \\
\hline ンルト質粘土 & 6 & 61 & 33 & 0.02 & 0.101 以下 & 95 & 1.43 & $\begin{array}{l}3.70 \times 10^{-7} \\
\left(3.78 \times 10^{-7}\right)\end{array}$ & $2.41 \times 10^{-7}$ & 1.39 \\
\hline ンルト質口ーム & 15 & 76 & 9 & 0.02 & 0.006 & 99 & 1.63 & $\begin{array}{l}8.86 \times 10^{-8} \\
\left(7.01 \times 10^{-8}\right)\end{array}$ & $6.87 \times 10^{-7}$ & 1.61 \\
\hline 粘士 & 3 & 47 & 50 & 0.008 & 0.001 以下 & 95 & 1.67 & $\left.2.92 \times 10^{-7}\right)$ & $1.64 \times 10^{-7}$ & 1.64 \\
\hline 土 & 2 & 48 & 50 & 0.008 & $"$ & 92 & 1.82 & $4.23 \times 10^{-7}$ & $3.22 \times 10^{-7}$ & 1.78 \\
\hline 土 & 8 & 42 & 50 & 0.01 & $"$ & 100 & 2.02 & $1.05 \times 10^{-7}$ & $2.27 \times 10^{-7}$ & 1.99 \\
\hline シルト質粘土ローム & 17 & 55 & 28 & 0.02 & " & 98 & 2.24 & $2.45 \times 10^{-7}$ & $3.37 \times 10^{-7}$ & 2.19 \\
\hline 粘 土 & 9 & 41 & 50 & 0.009 & " & 99 & 2.46 & $\begin{array}{l}2.38 \times 10^{-8} \\
\left(2.19 \times 10^{-8}\right)\end{array}$ & $2.00 \times 10^{-8}$ & 2.45 \\
\hline シルト質ローム & 15 & 77 & 8 & 0.02 & 0.003 & 99 & 1.89 & $6.90 \times 10^{-7}$ & $8.03 \times 10^{-7}$ & 1.83 \\
\hline シルト質粘土ローム & 3 & 27 & 70 & 0.003 & 0.001 以下 & 96 & 1.56 & $\begin{array}{l}6.45 \times 10^{-8} \\
\left(7.70 \times 10^{-8}\right)\end{array}$ & $9.17 \times 10^{-8}$ & 1.48 \\
\hline シルト質粘土 & 9 & 56 & 35 & 0.01 & $"$ & 100 & 0.86 & $\begin{array}{l}1.01 \times 10^{-8} \\
\left(1.20 \times 10^{-8}\right)\end{array}$ & $1.34 \times 10^{-8}$ & 0.85 \\
\hline
\end{tabular}

* の欄で，（）内の数值は変水頭測定法一匹により求めた值，その他は変永頭測定法一Iにより求めた值を示す。

**は密試験に際する載荷強度か： $0.2 \mathrm{~kg} / \mathrm{cm}^{2}$ の時の值を示す。

表一2 放射流式透水試験器による各種の土の透水実験例

\begin{tabular}{|c|c|c|c|c|c|c|c|c|c|c|c|c|c|}
\hline \multirow{2}{*}{ No. } & \multirow{2}{*}{ 試 } & \multirow{2}{*}{ 料 } & \multirow{2}{*}{ 名 } & \multicolumn{4}{|c|}{ 粒度配 合 (\%) } & \multirow{2}{*}{$\begin{array}{c}D_{16} \\
(\mathrm{~mm})\end{array}$} & \multirow{2}{*}{$\begin{array}{c}D_{10} \\
(\mathrm{~mm})\end{array}$} & \multirow{2}{*}{$\begin{array}{l}\text { 飽和度 } \\
(\%)\end{array}$} & \multirow{2}{*}{$\begin{array}{c}\text { 間げき比 } \\
e\end{array}$} & \multirow{2}{*}{ 測定法* } & \multirow{2}{*}{$\begin{array}{l}\text { 透 水 係 数 } \\
(\mathrm{cm} / \mathrm{sec})\end{array}$} \\
\hline & & & & 碎 & 砂 & ンルト & 粘 土 & & & & & & \\
\hline 1 & 荒 & & 砂 & 7 & 91 & 2 & 0 & 0.90 & 0.24 & 71 & 0.60 & 定 & $9.20 \times 10^{-2}$ \\
\hline 2 & & 砂 & & 0 & 94 & 6 & 0 & 0.50 & 0.12 & 92 & 0.66 & 定 & $7.30 \times 10^{-3}$ \\
\hline 3 & 標 & 準 & 砂 & 0 & 100 & 0 & 0 & 0.22 & 0.15 & 80 & 0.58 & 定 & $8.20 \times 10^{-3}$ \\
\hline 4 & 砂 質 & 口 & - & 0 & 69 & 21 & 10 & 0.10 & 0.005 & 76 & 0.70 & 定 & $7.37 \times 10^{-5}$ \\
\hline 5 & 口 & - & 么 & 0 & 46 & 48 & 6 & 0.062 & 0.011 & 95 & 1.47 & 変一I & $6.70 \times 10^{-6}$ \\
\hline 6 & ンル & 質口 & $1-4$ & 0 & 16 & 72 & 12 & 0.022 & 0.0055 & 86 & 1.37 & 変一I & $3.76 \times 10^{-6}$ \\
\hline 7 & シルト1 & 凟粘土 & ローム & 0 & 27 & 51 & 22 & 0.036 & 0.002 & 88 & 1.72 & 変一 I & $2.69 \times 10^{-6}$ \\
\hline 8 & 粘 & & 土 & 0 & 42 & 22 & 36 & 0.0095 & 0.001 以下 & 100 & 1.61 & 変-I & $\begin{array}{l}6.07 \times 10^{-7} \\
6.48 \times 10^{-7}\end{array}$ \\
\hline
\end{tabular}

* 定：定水頭測定法, 変一I：変水頭測定法一 I, 变- - II : 変水頭測定法一II

図一9透水試験試料土の粒径加積曲線

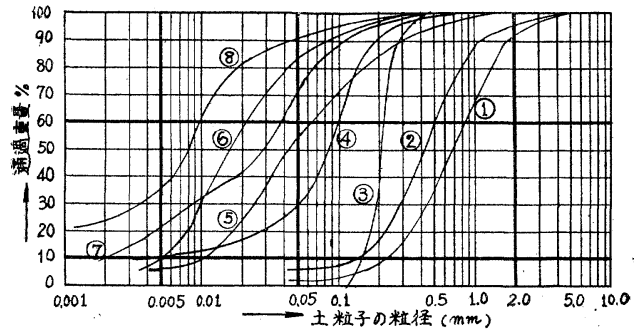

図一11 変水頭測定法一I における中央水頭降下 曲線之流速一動水勾配の関係の測定例 (その 2)

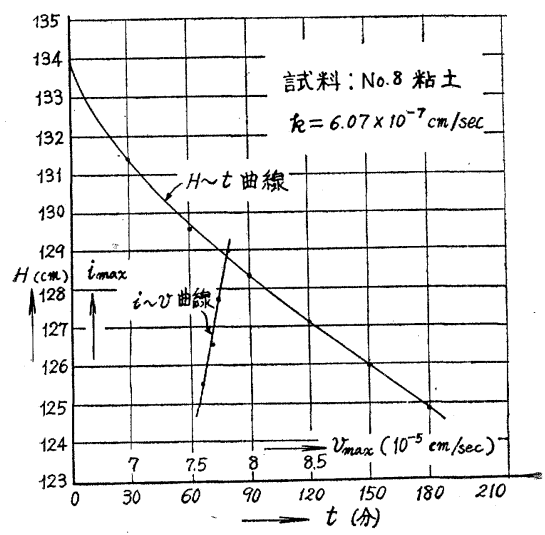

図-10 変水頭測定法一I における中央水頭 降下曲線之流速一動水勾配の関係の 測定例（その 1)

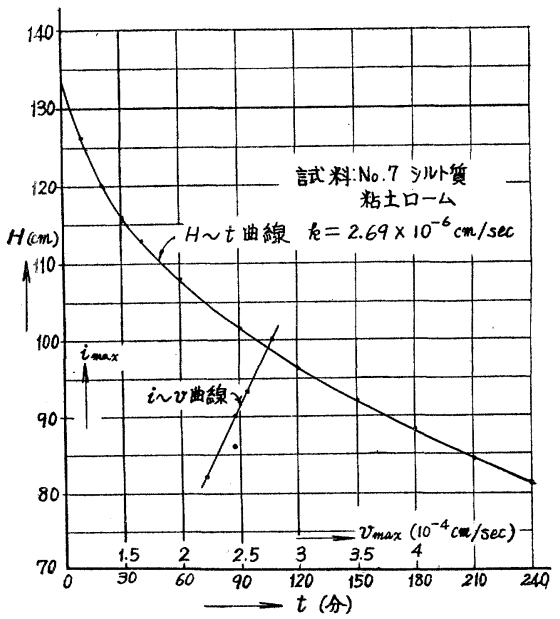


透水試験器にみられるような試験器の内側壁面と試料土との接触面からの漏水や, 試験中の攪乱, 膨張の恐れが なく，今までより一層精度の高い透水係数を測定することに成功した。特にこれまで $k=10^{-3} \sim 10^{-6} \mathrm{~cm} / \mathrm{sec}$ の範 囲の土は正確な透水係数を測定するのにかなりの経験を要し, また $k<10^{-6} \mathrm{~cm} / \mathrm{sec}$ の武料になると, 圧密試験の 結果からでなければ正確な透水係数が求められず，その測定には長い時間と手数がかかつたのであるが，放射流 式透水試験器は同一試験器で定水頭および変水頭の両測定法を実施することができ，ぞのような種類の土対し ても容易に相当の精度の測定值を得ることができる。また新しく考案した変水頭測定法一IIは $k<10^{-7} \mathrm{~cm} / \mathrm{sec} の$ 試料に対し特飞有効な測定法で, 精度も高いことが確認できた。

な特, 放射流式透水試験器は特飞水平方向の透水係数を求める場合飞便利である。試験器の直径を boring K よる採集試料の直径合わせて作つて拉けば，不攪乱試料の試験て好都合である。図一1 と示す試験器の構造の (7), (8)の部分には paraffin を注入することにしたが, 実験の結果 $k>10^{-6} \mathrm{~cm} / \mathrm{sec}$ の試料に対しては paraffin を 注入しなくても漏水の心配は全くないことが確かめられた。

この研究際しては, 日本大学教授 当山道三博士の指導を受けた。また九州大学教授 松尾春雄博士は, わざ わざ著者に有益なる助言と激励の詞を与えられた。記して両教授に衰心より敬意を表する。

\section{参 考 文 献}

1) M. Muskat: The Flow of Homogeneous Fluids Through Porous Media, 1937. p. 151.

2）例えば，河上房義：士の透水試験（その1），土と基礎，Vo1. 4，No. 1，1956. pp. 33〜40. に見られるような透水試験器をいう。

3) S. Leliavsky: Irrigation and Hydraulic Design, 1955. pp. 20 25.

4）河上房義：土の唀水試験（その1), 土と基礎, Vol. 4, No. 1, 1956. p. 34 .

5) D.W. Taylor: Fundamentals of Soil Mechanics, 1948. pp. 114 115.

6) 最上武雄：土質力学, 1951.p.64

7) D.W. Taylor: 前出, pp. 115 117

(昭.33.11.8) 